\title{
Intelligent Buildings: Key to Achieving Total Sustainability in the Built Environment
}

\author{
Tulika Gadakari ${ }^{1}$, Sabah Mushatat ${ }^{2}$, and Robert Newman ${ }^{3}$ \\ ${ }^{1} \mathrm{PhD}$ Student/Staff, Department of Architecture and Built Environment, Faculty of Science and Engineering, University \\ of Wolverhampton, Wulfruna Street, Wolverhampton, UK, E-mail: t.gadakari@wlv.ac.uk (corresponding author). \\ ${ }^{2}$ Professor, Department of Architecture and Built Environment, Faculty of Science and Engineering, University of \\ Wolverhampton, Wulfruna Street, Wolverhampton, UK, E-mail: s.mushatat@wlv.ac.uk \\ ${ }^{3}$ Professor, Department of Maths and Computer Science, Faculty of Science and Engineering, University of \\ Wolverhampton, Wulfruna Street, Wolverhampton, UK, E-mail: r.newman@wlv.ac.uk
}

Engineering Management

Received May 31, 2013; received revision July 12, 2013; accepted July 27, 2013

Available online December 13, 2013

\begin{abstract}
Are intelligent buildings a pragmatic approach towards achieving a sustainable built environment?' is the research question that this review article aims to answer. It has been argued that there is a serious need for intelligent buildings to be evaluated against the parameters of total sustainability (environmental, economic and social) so as to help the agenda of living in a technologically advanced, healthy and comfortable world. This paper reviews existing theoretical concepts of intelligence and sustainability in the built environment, through an exploration of various scientific literature and U.S Green Building Council's LEED (Leadership in Energy and Environmental Design) databases. A systematic qualitative review approach has been employed to select an appropriate definition of sustainable development and use it as a theoretical framework to assess the technological impact of intelligent buildings on the environmental, economic and social front. Subsequently five case study buildings from around the world, which exemplify the use of intelligent technologies to achieve sustainable gains were chosen and analyzed to further validate the literature findings. Outputs from the study highlight the various benefits of intelligent buildings, which include decrease in energy and water consumption, operational costs, as well as increase in productivity and investments. Additionally the analysis of the case studies revealed that the use of intelligent building technologies has contributed significantly towards a higher sustainability rating on the LEED rating scale. Moreover, the comparison of the attributes of intelligent buildings and sustainable practices in buildings, illustrates the fact that there is a considerable overlap between the two and intelligence can aid sustainability in the built environment. Thus the research suggests that green technologies and intelligence in combination may be a pragmatic approach towards the sustainability aspect.
\end{abstract}

Keywords: Intelligent buildings, green buildings, smart buildings, innovative architecture, sustainability

\section{Introduction}

The Information Age also commonly known as the Digital Age has brought about fast evolution of technology in daily life and allowed rapid global communications and networking to shape modern society. This phenomenon has spurred progress in all fields including the built environment (Kluver, 2000). The advent of computer integrated systems and controls have caused quite a dramatic shift in the building industry. Intelligent buildings that originated in the early 1980's in the United States, are fast-spreading their tendrils as the elements of the digital information revolution. (Harrison et al., 1998; Mazza, 2008) An intelligent building is in essence one that integrates disparate building systems such as lighting, HVAC, safety, security, power management, shared network, voice and data communication, etc. to effectively manage resources in a coordinated mode and provide significant high performance benefits. An ideal intelligent building should provide a dynamic and responsive infrastructure using technology so as to optimize processes, comfort, flexibility, effectiveness, energy efficiency, costs and environmental benefits. (Clements-Croome, 1997; Harrison et al., 1998; Sharples et al., 1999; Wacks, 2002; Damodaran, 2006; Clarke, 2008; Madsen, 2008b) Although there is no standard recognized definition available, the most expressive definition of intelligent buildings is the one proposed by Bennett et al. (1987) (in Atkin, 1988), which comprehensively highlights the attributes that an intelligent building should possess:

- "Buildings should 'know' what is happening inside and is immediately outside.

- Buildings should 'decide' the most efficient way of providing a convenient, comfortable and productive environment for the occupants. 
- Buildings should 'respond quickly to occupants' requests",

Within the past 30 years or so, the notion of building intelligence has evolved owing to technological maturity; introduction of web-enabled integration platforms and IPenabled devices; solid industry standards; substantial cost reduction; and increased market demand (Ehrlich, 2007). This has enabled intelligent buildings to be mainstream, practical and economical than before. A plethora of intelligent components and products that have been introduced and made available in the building industry over the last few years, are a testimony to the same (Harrison et al., 1998). Microsoft's home of the future is a good example, which is stocked with the latest technology that is refreshed every year to showcase state-of-the-art innovations. Some of the technologies on display include:

- surface technology-enabled coffee table that creates a life-like environment on screen via detailed, 360-degree images so that one can browse merchandise, talk to a store worker or visit art galleries from the comfort of home;

- advanced home security systems;

- smart kitchen countertops that can assemble a grocery list, suggest recipes based on available items in the pantry and refrigerator and help with recipes as well as easy data transfer;

- touch-sensitive OLED screens hidden under the wall's paint that are interactive and can change to match many moods;

- wall-sized displays in the dining room that use cloud services to project health \& diet information;

- mirrors that give fashion advice;

- sensors that notify when plants need water; and an interactive home computer system named 'Grace'. (Lai, 2006; O'Neill, 2010).

Siemens Building Technologies, estimates on the basis of current technological progress and market sales, an additional market potential for intelligent building systems of some US\$26 billion over the coming ten years (Clarke, 2008). International Data Corporation (IDC) also estimates that the global smart building market will grow from US\$3.1 billion in 2010 to US\$10.2 billion by 2015 (Kolodny, 2011). The study of current technological progress and speculation of future advances in the fields of artificial intelligence, robotics, automation, and architecture, confirm that intelligence in buildings is a sign of technological sophistication which will improve in leaps and bounds as time progresses (Nikolaou et.al., 2004; Kurzweil, 2005). With all the ingredients for the high-tech option falling into place Futureagenda (2011) foresees, by 2020, "that the majority of new buildings being constructed around the world, and many that are being refurbished, will be increasingly intelligent". Atkin (1988) reiterates, "Intelligent buildings are not a fad, but simply progress" with the future foreseeing a huge growth potential.

On the one hand we have the scientific and technological revolution that has brought us tremendous improvements in various fields and on the other we have problems such as global warming, resource depletion, deforestation, irresponsible urbanization, etc. (Garner, 1996; Harris, 2004a; Pitts, 2004). It has been observed that "the total annual emissions of $\mathrm{CO}^{2}$ have increased from 1.5 million tonnes in the 1950s to almost 6 billion tonnes in the 1990s, and it is further predicted that $\mathrm{CO}^{2}$ concentrations will double by the year 2050 unless action is taken" (Simpson, 1990; Pickering and Owen, 1994; in Garner, 1996). Sustainable development is one of the rising issues of concern that has peaked with the advent of the 21 st century. Buildings are responsible for at least $40 \%$ of energy consumption in most countries (Frost and Sullivan, 2009). They are resource intensive in construction and operation; they also produce enormous quantities of emissions and waste during the construction process, during their period of use and occupation, and also at the point of their eventual demolition (Nikolaou et al., 2004; Pitts, 2004). A report from the SMART 2020 programme forecasts that, with increasing urbanization, worldwide energy consumption for buildings over the next 20 years will grow by around 45\% (Futureagenda, 2011). These projections identify buildings as a sector with the most potential for improvement to meet the targets for reducing the threat of climate change (Nikolaou et al., 2004; Pitts, 2004). As energy prices climb and the focus on environmental performance intensifies, buildings will have to make extra efforts to steer towards the sustainable way.

Gore (2006) uses simple formulae to illustrate the effects of using powerful technologically enhanced inventions with limited vision and age-old habits.

\section{"Old habits + Old technology = Predictable consequences}

Old habits + New technology $=$ Dramatically altered consequences",

He claims that new technology coupled with old unsustainable habits can magnify the consequences, which have not yet been anticipated and can pose brand new problems for the future. In this context it can be implied that intelligent buildings, if not coupled with sustainable practices can lead to unanticipated side effects. On the other hand, intelligent buildings being sustainable stand to make a huge positive difference on the environment. Though there exists a dilemma as to whether intelligent buildings promote sustainability or not? Common perception in the intelligent building industry reveals that intelligence can aid sustainability but there is still doubt among stakeholders who view its use as an overtly luxurious lifestyle negating the purpose of sustainable living (Frost and Sullivan, 2009). There have been two prominent schools of thought; one that believe that a 'sustainable building' can be achieved using intelligent building systems while the other which argues that more energy and money can be saved by using natural energysaving design solutions (Clarke, 2008; Moore, 2009b).

This review article aims to study the existing theoretical concepts by analyzing literature and case study buildings. It has been argued that since intelligence in buildings is on the rise, it is of great importance to determine if this outcome is sustainable for the future or not. In the light of the discussion, this paper aims to answer the following research question 'Are intelligent buildings a pragmatic approach towards achieving a sustainable built environment?' 


\section{Methodology Employed}

A systematic qualitative review approach was used to gather, analyze, grasp and report the fundamentals of the current state of knowledge. The research platform was setup in the areas of sustainability; definition and evolution of intelligent buildings; types of intelligent building technologies; and components of intelligent buildings such as sensors, building systems, level of integration and facilities management. The exhaustive review list comprised of journal articles; books; web based articles; white papers; magazine articles; theses; government and private organisation reports; project reports and USGBC's LEED (Leadership in Energy and Environmental Design) database. The literature was reviewed across specific topics and themes pertaining to the research question so as to provide a holistic understanding of intelligent buildings and sustainability in the built environment context. The following criteria was pre-determined to ascertain the eligibility and relevance of the literature chosen: effect of intelligent building technologies on energy, $\mathrm{CO} 2$ emissions, water consumption, operational costs, ROI, payback periods, productivity, safety, comfort, well-being and occupant behavior. An objective and transparent approach for research synthesis was followed with the aim of minimizing bias.

Sustainability is a concept whose definition can be interpreted according to the context it is used in (Mitchell, 1998). Various definitions of sustainability were explored before choosing an appropriate definition of sustainable development whose principles align with this study related to technological development. This definition was then used as a theoretical framework to study intelligent buildings. The concepts of environmental, economic and social sustainability were used as indicators to judge the orientation of intelligent buildings with total sustainability.

Next, five commercial buildings from around the world were selected and studied as they exemplified the benefits of using intelligent technologies for achieving sustainable gains. The case study buildings chosen were Herman Miller International Headquarters, UK; The U.S. Green Building Council (USGBC) Headquarters, USA; Genzyme Centre, USA; Asia Square Tower 1, Singapore; and Taipei 101 Tower, Taiwan. All of these buildings were accredited by the LEED rating system as being highly sustainable buildings i.e. 'GOLD' and 'PLATINUM'. The LEED system evaluates the level of sustainability of a building on a scale ranging from 'CERTIFIED' to 'SILVER' to 'GOLD' and finally 'PLATINUM', where PLATINUM is the highest rating available. A case study research approach was utilized to help answer the research question and validate the literature findings with data obtained in a real-world context.

In a nutshell, the emphasis of this review paper lies in the analysis of intelligent buildings against the principles of total sustainability to reveal their benefits and limitations.

\section{Redefining Sustainability in the Built Environment Context}

In 1987, the most widely quoted definition of sustainability was coined by the United Nations in the report of the World Commission on Environment and Development (WCED): Our Common Future (also known as The Brundtland Report).

"Development that meets the needs of the present without compromising the ability of future generations to meet their own needs" (WCED, 1987).

John Elkington laid down the 'three pillars' of sustainability or the 'triple bottom line' in 1994, which required the reconciliation of environmental, social and economic demands (Elkington, 2004). There are a wide range of definitions available, which goes on to show that sustainable development can be interpreted to have economic, social, political or environmental dimensions, depending on the values and the goals of the individual (Mitchell, 1998). Hence a universally accepted definition of sustainability remains elusive, till date. Many people, including professionals such as architects, engineers, town planners, etc. have hitherto considered sustainability to be a synonym for energy-efficiency (Harris, 2004a). Scott (1998) asserts that sustainability is not only about energy efficiency but also about people's comfort, well-being and cost savings. Alnakib (2004) reiterates that the three dimensions of sustainability are mutually reinforcing to translate sustainability in an architectural setting.

This study adopts the definition of sustainable development by the World Commission on Environment and Development (WCED) (1987) owing to the multiplicity of issues embraced within it. This definition encompasses the three dimensions of sustainability and also adds to it another dimension of technological development that holds very critical to this study involving intelligent buildings.

"Sustainable development is a process in which the exploitation of resources, the direction of investments, the orientation of technological development and institutional change are all in harmony, and enhance both current and future potential to meet human needs and aspirations" (WCED, 1987).

\section{Using the Definition of Sustainability to Evaluate Intelligent Buildings}

The introduction of novel practices such as the use of intelligence in architecture is questionable and needs to be scrutinized under the critique microscope until its benefits as well as limitations are analyzed. The advantages shall help in validating the role of intelligent buildings and the disadvantages are gaps, which provide scope for further study. The definition of sustainable development has been used as a theoretical framework to study intelligent architecture. The dimensions of sustainability i.e. environmental, economic and social are explored in the intelligent buildings context. The premise being explored is the increasing awareness of the technological impact of intelligent buildings on the environmental, economic and social front. (Gadakari et al., 2012) 
Table 1. Energy savings, annual GHG / CO2 emission reduction and payback period (Source: Frost and Sullivan, 2009)

\begin{tabular}{|c|c|c|c|c|}
\hline Case Study & Energy Savings & $\begin{array}{l}\text { Annual GHG / CO2 } \\
\text { Emission Reduction }\end{array}$ & Payback Period & $\begin{array}{l}\text { Technology Trade } \\
\text { Names }\end{array}$ \\
\hline $\begin{array}{c}\text { State of } \\
\text { Missouri, } \\
\text { Missouri, USA }\end{array}$ & $\begin{array}{l}\text { 17\% annual energy } \\
\text { savings (post } \\
\text { retrofit) }\end{array}$ & $\begin{array}{c}\text { Eliminated } 205 \text { million } \\
\text { pounds of } \mathrm{CO} 2 \text { equivalent } \\
\text { emissions, an amount equal } \\
\text { to the annual } \mathrm{CO} 2 \text { emissions } \\
\text { of } 40 \text { coal-fired power } \\
\text { plants }\end{array}$ & $\begin{array}{c}\text { Payback in less than two } \\
\text { years }\end{array}$ & $\begin{array}{c}\text { Enterprise Asset } \\
\text { Management \& } \\
\text { Building Information } \\
\text { Management System }\end{array}$ \\
\hline $\begin{array}{l}\text { Rogers Centre, } \\
\text { Toronto, } \\
\text { Canada }\end{array}$ & $\begin{array}{l}76 \% \text { savings on } \\
\text { lighting energy } \\
\text { costs (post retrofit) }\end{array}$ & $\begin{array}{c}\text { Reduced CO2 emissions by } \\
2797 \text { tons annually, the } \\
\text { equivalent to taking } 465 \\
\text { passenger vehicles off the } \\
\text { road }\end{array}$ & $\begin{array}{l}\text { Phase One:Payback in } \\
\text { three years } \\
\text { Phase Two: Payback in } \\
\text { two-and-a-half years }\end{array}$ & $\begin{array}{l}\text { Energy Control } \\
\text { System (ECS) }\end{array}$ \\
\hline $\begin{array}{l}\text { The Verve- } \\
\text { High Rise } \\
\text { Condominium, } \\
\text { Toronto, } \\
\text { Canada }\end{array}$ & $\begin{array}{l}35 \% \text { annual energy } \\
\text { savings compared to } \\
\text { local energy code } \\
\text { (similar to } \\
\text { ASHRAE 90.1) }\end{array}$ & $\begin{array}{l}\text { Annual GHG reductions due } \\
\text { to energy efficiency } \\
\text { measures equaling } 887 \text { tons, } \\
\text { equivalent to } \mathrm{CO} 2 \text { emissions } \\
\text { from } 91,336 \text { gallons of } \\
\text { gasoline }\end{array}$ & $\begin{array}{l}\text { LEED premiums } \\
\text { Payback in seven years } \\
\text { or less }\end{array}$ & $\begin{array}{l}\text { Energy Management } \\
\text { Systems (EMS) }\end{array}$ \\
\hline
\end{tabular}

\subsection{Environmental Sustainability}

The world is facing new challenges over global warming and long-term supply of fossil fuels. This, combined with the pressure of an aging electrical generation infrastructure, is putting the onus on new programs for high efficiency buildings. Mitchell (1998), Gray (2006), Ehrlich (2007), Rios-Moreno et al. (2007), Moore (2009a), Liu et.al. (2010) and Schultz (2010) observe that programs promoting energy efficiency need to have an intelligent system design as one of their core elements. They note that by integrating communications, computing, control and building systems on a unified network, manageable from a unified operations centre, an intelligent building can optimize its physical infrastructure and lead to energy efficiency. They account their hypothesis to the varied functions of intelligent control systems such as stop and start equipment; monitoring space conditions and occupancies; and implementing sophisticated strategies.

A building that knows when and where it is occupied can limit its own energy use by confining the operation of power-hungry HVAC and lighting systems to the hours and areas of the building they are needed ( $\mathrm{Wu}$ and Noy, 2010). Intelligent buildings can also anticipate the energy loads needed, based on fuzzy logic and learning from the day before or previous weather conditions and understand what they need to do to respond accordingly (Schultz, 2010). These tasks employ the use of various type of sensors for enhanced presence detection and accurate localized occupancy information to provide solutions that are energy-efficient (Dounis et al., 2011; Pandharipande and Caicedo, 2011). It is observed that sensors can pay for themselves through energy savings within a few years. Thus, in most cases, sensors offer greater energy savings and more flexibility than other forms of control and have proved to work effectively in a variety of applications. (Barnes et al., 1998; Wu and Noy, 2010)

The SMART 2020 programme, informs that intelligent buildings and accompanying smart grids will save around 4 gigatonnes of $\mathrm{CO} 2$ equivalent emissions in 2020
(Futureagenda, 2011). IBM estimates intelligent buildings can reduce energy consumption and $\mathrm{CO} 2$ emissions by $50 \%$ to $70 \%$ and save $30 \%$ to $50 \%$ in water usage (Moore, 2009b). Johnson Controls, a leading producer of energysaving equipment, says companies can cut energy bills by $20 \%$ to $25 \%$ by using efficiently programmed and monitored building management systems and other intelligent controls (Mazza, 2008). They explain that the biggest savings come through management of heating and cooling- "One degree Centigrade down in heating temperature will provide around $7 \%$ savings on the energy necessary to heat the building." (Clarke, 2008)

Frost and Sullivan (2009) studied certain buildings that were prominent examples of intelligent buildings in the US and Canada to determine the effect intelligent technologies have on energy savings, greenhouse gas and $\mathrm{CO} 2$ emissions (Refer Table 1).

Matthew et al. (2009) conducted a survey of intelligent and non-intelligent buildings in India, to provide insights on the comparative energy efficiency of buildings and to find out whether the investment on intelligent buildings has any impact on the long-term economy. Three office buildings were chosen with varying levels of intelligence such that Intelligent Building 2 (IB2) was the most intelligent among the three; Intelligent Building (IB1) was lower in intelligence than IB2; and the third building (nonIB) was conventional with no inclusion of intelligent technologies. It was evident that IB2 has the least 'Annual energy expense per sq.m.' while the non-IB has the maximum. Also between the two intelligent buildings compared, IB2 saves almost two and a half times more money than IB1. This goes on to highlight that intelligent buildings reduce energy usage as compared to conventional ones and also the higher the level of intelligence of a building the greater are the energy savings.

Despite all the potential energy saving benefits that have been highlighted Matsunawa and Nohara (1994) claim that intelligent buildings use a lot of energy. 
Engineering and construction company, Jacobs, asserts that incorporating methods such as better building design and passive or natural energy-saving solutions can save more energy (Damodaran, 2006). Architecture firm, Architype, argues passive solutions are more sustainable because they don't need to be updated or refreshed during their lifetime and continue doing their job as long as the building lasts (Elkadi, 2000). Newsham et al. (2009) also highlights a contrary view through a questionnaire based study that personal environment control resulted in an average energy reduction of around $10 \%$ as compared to the typical intelligent fixed system.

\subsection{Economic Sustainability}

Economic sustainability is a tool to make sure the business is making a profit while addressing environmental concerns and contributing to the financial welfare of the owners, the employees, and the community where the business is located.

"A probable stereotype of an intelligent building is that it is a possession of technologically advanced countries" (Kua and Lee 2002). This is a common preconception nurtured due to the perceived economic burden that an intelligent building poses. Himanen (2003), Gray (2006), Katz and Skopek (2009) and Matthew et al. (2009) recognise the benefits of the 'Intelligent building concept' as decrease in building maintenance and energy costs; increase in productivity, rental incomes, investments, occupancy rates, retention; and accommodation of flexibility. Johnson Controls, speculates "over a period of 40 years, it is estimated that only $11 \%$ of the total cost of a facility goes into the initial construction of the building; $14 \%$ into financing; $25 \%$ into operations and $50 \%$ into operational expenditure" (IT-Online, 2012). They identify the true cost of an intelligent building as not simply its cost of construction but also the operation and maintenance costs over the structure's life span. Intelligent buildings also guard against productivity loss, revenue loss, and loss of customers to competitors. As all of these are critical factors for the success of a business, owners have an advantage by investing in an intelligent building to reinforce the future of their business.

As noted by the Intelligent Buildings International (IBI) Group, intelligent buildings yield cost reductions in operation and maintenance through optimizing automated control, communication and management systems. For example by using an intelligent security system one security guard can efficiently keep an eye on security functions; track people in the building; lock and unlock doors; and monitor the fire system from a single location. Thus making the operation cost-effective by eliminating the need for a group of security personnel making rounds. (Clarke, 2008) The 46,450 sq.m. campus of Ave Maria University, Naples is also an example of reduced operating costs owing to the use of intelligent integrated systems. Ave Maria University saved over US\$1 million in building costs by eliminating the redundant wiring and cabling of multiple isolated building systems; reduced staffing costs by US $\$ 350,000$ annually by enabling IT to assume tasks of building maintenance staff; and enabled significant efficiencies in utility usage (Frost and Sullivan, 2009). The estimated cost of the project was between US\$0.32 and US\$0.38 per sq.m., but the operating costs stood at about US\$0.28 per sq.m. for utilities, thus saving the university a lot of money (Madsen, 2008b).

Intelligent Buildings can also provide an immediate return-on-investment and reduce the expected time of payback in terms of higher employee productivity and reduced operating expenses (Katz and Skopek, 2009). According to a study by Himanen (2003) "it has been calculated that in office work the cost of labour is 80 per cent, other costs 10 per cent, and the space costs 10 per cent (Mölsä, 1991; Anttila, 1991; Martela et al., 1991), or alternatively 86 per cent, 9 per cent and 5 per cent (Huhtanen 2000). Hence, the small increase in work productivity can easily pay back the investment costs, especially if it is true that the cost of building automation is 1 per cent of the total building investment". Frost and Sullivan (2009) report an average expected payback time of intelligent building technologies to be three and a half years or less, after studying some buildings that were prominent examples of intelligent buildings in the USA and Canada (Refer Table1)

Hartman (2005) evaluates the potential benefits of advanced technologies by a comparison between the electric energy usage of a cooling system, for an office building in south western USA, when an optimized conventional system (grey bars) is reconfigured to a network based system (black bars) of the same first cost. It was observed that the electric energy budget for cooling was cut about in half when the conventionally optimized cooling system was reconfigured for network controls, without increasing the cost of the system.

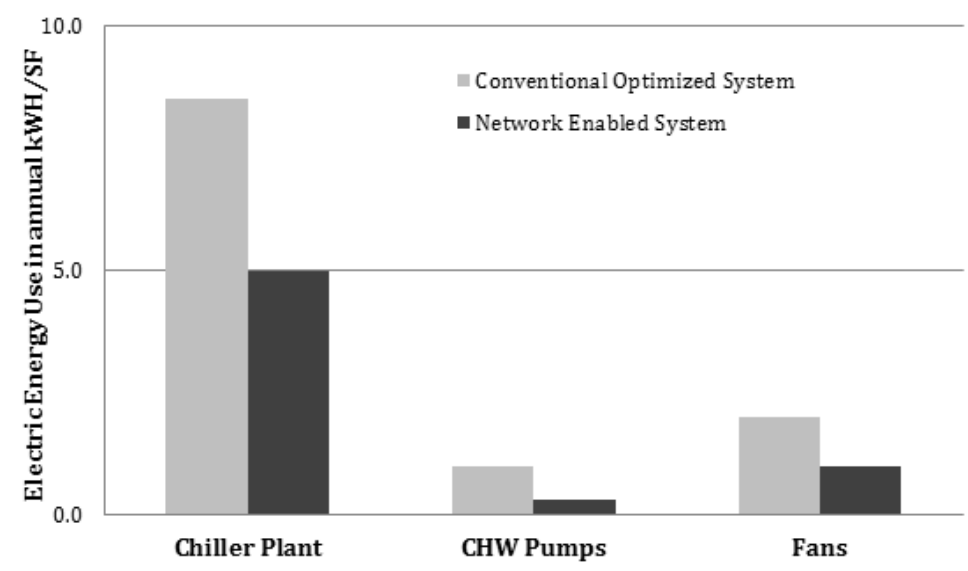

Fig. 1. Conventional optimized control vs. network control: cooling system electric use per square foot for an office building (Source: Hartman, 2005) 


\subsection{Social Sustainability}

Social sustainability is the idea that "future generations should have the same or greater access to social resources as the current generation (inter-generational equity), while there should also be equal access to social resources within the current generation (intragenerational equity)" (Sen, 2000). Social sustainability in the built environment ensures respect for the iterative cycle of human mental need for freshness, concentration, safety and relaxation in order to work effectively (Clements-Croome, 1997). The social implication of intelligent technologies on our lifestyles needs delicate attention so as to ensure an enriching environment to make life meaningful amidst all the technological progress (Gadakari et al., 2012).

Riewoldt (1997) and Mazza (2008) assert intelligent spaces should use technology to humanize living environments and help reunite people with their sociocultural and natural environment in aesthetic, ergonomic and ecological terms. Maximizing occupant comfort, acceptability, performance, safety and efficiency are the recipe for social sustenance of intelligent buildings. Cole and Brown (2009), Chappells (2010), Chen et.al. (2010), Karjalainen (2010) and Liu et al. (2010) encourage the shift from a technology-centred view to socio-technical interactions of the occupants and pervasive spaces. They believe that there is a necessity to learn and predict human behaviour as well as accommodate human intelligence in context of automation so as to achieve intelligent and sustainable environments. For example in several intelligent office buildings, when an employee comes to work out of hours, a swipe of his security badge triggers the heating and lighting in his office area to power up, such that the space is perfectly heated or cooled and welcoming on his arrival. The coordination of various systems on an unified network also ensures that upon receiving an external camera feed of a man running towards the building from the parking lot, the intelligent security system engages locks on entry points and alerts security personnel to a potential problem. (Schultz, 2010)

Clements-Croome (2004) highlights the social responsibility of intelligent buildings as facilitating "social ambience, convenience, security, safety, sensory stimulation, freshness and a pleasant climate". The Building Research Establishment (BRE) is currently managing a research project called the Assisted Living Innovation Platform, which explores the role of new and improved intelligent technologies in future buildings and communities. Some of the smart features that promote the interactive social element are assistive technologies; remote monitoring (i.e. telecare) to manage risk and to provide information, advice, health coaching and response to emerging problems; and virtual presence interfaces and applications to overcome loneliness, isolation \& depression and to enable people to socialize. (BRE, 2011)

Recent advancements in pervasive computing allow embedded systems to collect information for context awareness and apply it in ways that result in new advanced services and applications. These advances in technology have changed the definitions of comfort and productivity as well as resulted in the assessment of a completely different set of issues pertaining to privacy in intelligent spaces. Liu et al. (2010), Karjalainen (2010) and Moran and Nakata (2010) analyze a series of factors pertaining to monitoring and surveillance, which are believed to influence occupant behaviour, from both physical and social perspectives. The problem areas identified are device obtrusion, coverage and control; number of devices; frequency of data collection; and user awareness.

Some of the most frequently asked questions to evaluate the role of human intervention in an intelligent environment are, whether people prefer to be in charge of their surroundings or are perfectly satisfied by the independent job done by the intelligent building systems? Do monitoring and surveillance influence occupant behaviour? How much level of technological intrusion is considered healthy? Matthew et al. (2009) analyzed the effect of intelligent security systems on employee efficiency. This study highlighted that the entry control devices inconvenienced majority of the people (around 70$80 \%$ ) but at the same time they felt secure at their workplace. The entry control devices did not affect around $10-15 \%$ of the people. $60-70 \%$ people reported feeling secure in the presence of closed circuit cameras. While 20$30 \%$ people felt that their efficiency had improved as they felt their superiors were monitoring them. Farinloye et al. (2013) share the view that spaces can be better protected through the use of stand-alone or integrated CCTV and alarm systems that are motion sensitive and infrared enabled. The added use of a digital video recorder (DVR) camera device that accepts analog signal from the security camera and converts it to digital format allows the setting of motion detection features and alerts off-site monitoring when activated. Baird and Lechat (2009) conducted a survey to determine the amount of personal control building users had and whether they considered it to be important. Responses were sought concerning the following aspects of the working environment: heating, cooling, ventilation, lighting and noise. For the set of buildings studied it was found that the users' perceived the amount of personal control they had of lighting to be reasonable, but that for heating, cooling, ventilation and noise was relatively low. Around $30 \%$ of respondents saw it as important to have this control. It was suggested that reaching an optimum solution with user control and automation helps people have a choice and feel comfortable in the environment.

Kua and Lee (2002) have introduced the 'Intelligent Building Initiatives' that could be used to encourage social acceptance of intelligent building technologies in an unintimidating way by the general public. This initiative introduces concepts such as:

- intelligent centre featuring intelligent technologies in a fun and thought-provoking way;

- intelligent laboratory housing specialized research and testing of technologies;

- volunteers try-out program to improve the client's general knowledge on intelligent technologies;

- industry co-opting program for outreach and collaboration with industry; and

- technology adaptations and collaborations program to promote academic collaboration between countries of different technological capacity. 
Table 2. Summary of findings

\begin{tabular}{|c|c|c|c|}
\hline Outcomes & Environmental & Economic & Social \\
\hline $\begin{array}{c}\text { Advantages of Intelligent } \\
\text { Buildings }\end{array}$ & $\begin{array}{l}\text { - Energy efficiency } \\
\text { - Automatic response to } \\
\text { change in energy loads } \\
\text { - Reduction in GHG and } \\
\text { CO2 emissions }\end{array}$ & $\begin{array}{l}\text { - Decrease in building } \\
\text { operation, maintenance and } \\
\text { energy costs } \\
\text { - Increase in employee } \\
\text { productivity } \\
\text { - Increase in rental incomes, } \\
\text { investments and occupancy } \\
\text { rates } \\
\text { - Immediate return on } \\
\text { investment } \\
\text { - Reduced payback period }\end{array}$ & $\begin{array}{l}\text { - Increase in occupant } \\
\text { comfort and well-being } \\
\text { - Increase in employee } \\
\text { productivity } \\
\text { - Increased sense of safety } \\
\text { and security } \\
\text { - Helps overcome loneliness, } \\
\text { isolation and depression }\end{array}$ \\
\hline Disadvantages & $\begin{array}{l}\text { Passive sustainable solutions } \\
\text { reported better energy } \\
\text { savings as opposed to } \\
\text { intelligent buildings in a } \\
\text { handful cases studied }\end{array}$ & None & $\begin{array}{l}\text { - Lack of privacy } \\
\text { - Inconvenience due to } \\
\text { devices } \\
\text { - Feeling a sense of loss of } \\
\text { control over surroundings }\end{array}$ \\
\hline
\end{tabular}

\subsection{Summary}

Table 2 is a summary of the advantages and disadvantages of intelligent buildings when assessed on the basis of the definiton of total sustainability encompassing environmental, economic and social criteria.

\section{Intelligent Building Case Studies}

In order to further highlight and validate the significant impact of intelligent building technologies on sustainability in the built environment, five buildings were chosen from around the world, namely UK, USA, Singapore and Taipei. Each of these buildings are a showcase of the state-of-art intelligent systems and have also been accredited by the LEED rating system as being highly sustainable buildings.

\subsection{Herman Miller International Headquarters, UK}

VillageGreen, the Herman Miller International Headquarters is a 2200 sq.m. facility housing offices, retail and a data centre in Chippenham, UK. The environmentally friendly new headquarters acquired a 'GOLD' rating from LEED. (Herman Miller, 2013) It boasts of a wide variety of intelligent features and was delivered for the same cost as a standard commercial building (Designbuild-Network, 2012).

A computerized ventilation system adjusts airflow and no air conditioning is needed. The window has a motorized fanlight opening, which is controlled automatically and adopts a pulsed ventilation strategy. The window opens periodically for a short time to release stale air. An automatic night-cooling strategy operates during the summer months to purge the building of heat built up during the day. The automatic controls monitor the internal conditions through sensors in the floor slabs as well as external conditions such as wind speed \& direction, rainfall and solar radiation. (Parker, 2009) Water meters have been installed to monitor water flow and detect leaks to help prevent wastage (Designbuild-Network, 2012).

The lighting and small power for the office space on the first floor is metered separately from the showroom on the ground floor due to which the difference in power consumption of the two spaces can be noted. The first floor office space uses sensor controlled lighting strategy, detecting both lighting levels and movement, while the showroom on the ground floor is manually controlled. The first floor lighting consumes around $27,000 \mathrm{kWh}$ per annum, while the showroom consumes $111,300 \mathrm{kWh}$ per annum over a smaller floor area. Gas consumption for space heating and domestic hot water is also well below the good practice benchmark in the Building Regulations. (Parker, 2009; Herman Miller, 2013)

To ensure staff safety, the building uses photographic identity cards for out of hour's access and restricted zones. CCTV cameras cover the car park 24 hours a day. Plasma screens and videoconference equipment is fitted in most rooms, to pick up presentations from the network or to link people with their other offices, all over the world. (Herman Miller, 2008) FileLine, an electronic document management system, helps reduce storage space needed for printed documents and helps staff efficiency (Workplace intelligence, 2012).

\subsection{The U.S. Green Building Council (USGBC) Headquarters, USA}

The USGBC office (6850 sq.m.) serves as a living lab and demonstrates through its sophisticated and advanced green building design and technology that intelligent buildings can achieve the highest rating for sustainability on the LEED scale i.e. 'PLATINUM'. The project used $60 \%$ less energy and achieved $40 \%$ water savings than a typical code-compliant office. All the energy efficient strategies have resulted in a US\$96,000-per-year saving as well as the additional investments needed have a low payback period. But the USGBC believes that the greatest return on investment they have accomplished is from increased staff productivity. (Gonchar, 2009; USGBC, 2009; USGBC, 2012a)

A high performance lighting system is used, that is controlled off of an IT backbone and controls light switching, dimming and allows very specific energy use monitoring. This led to a reduction in the lighting power 
density by $50 \%$ and a $15 \%$ drop in the energy usage (USGBC, 2009). Lights can be programmed to automatically turn on and off or dim, and switches can also be adjusted to determine which lights they control and how they function. For example, there can be a different setting if someone just taps a switch versus holds it down for a length of time. The lighting system also allows for future flexibility as it can be easily reprogrammed. (USGBC, 2012a) Motorized window shades are automatized to reduce glare and improve natural day lighting. (Gonchar, 2009)

Occupancy sensors were used to control lighting in private offices as well as in the clusters associated with workstations. Occupancy sensors also helped control and lower plug loads by turning them off when not in use. Additionally the integration between lighting controls and automated temperature modulation resulted in significant energy savings when workstations are unoccupied. Not only does the system turn off lights in the unoccupied areas but it also turns off the miscellaneous power. The system also re-sets the thermostats when someone in a private office goes to a meeting. When the office is unoccupied there is no need to maintain precise temperature control but it is important that when the occupant returns from a meeting that the space be at a favourable temperature. The system can offset the temperature by a three to five-degree Fahrenheit variable (67 to 72 degrees) based on the user so that when the occupant returns, the space can regain proper temperature quickly making the space usable and save energy costs. (USGBC, 2012a)

A new technology was used that significantly removes the thermal downdraft by redirecting airflow based on air temperature i.e. when the diffuser senses warm air, the pattern controller pushes the air down the glass; when it senses cold air, the pattern controller flips and the air is discharged close to the ceiling. This two-position diffuser uses no electricity and operates off of an internal thermostat. (USGBC, 2012a) Other value adding, efficient strategies included a building commissioning plan, lowflow/waterless urinals, low-flow fixtures, sub-metering, MEP shades, a smart grid and ENERGY STAR appliances. (Gonchar, 2009)

\subsection{Genzyme Centre, USA}

The Genzyme Centre located in Cambridge, Massachusetts, hosts the biotech company's offices in a 32,000 sq.m. LEED certified 'PLATINUM' rated building. The building's efficiency is optimized by the use of an integrated building management system that controls all 30,000 automation points in the building. This extensive building management system along with efficient equipment have reduced the projected overall energy cost of the building by about $41 \%$. (Behnisch-Architekten, 2012; USGBC, 2012b)

The building envelope is a high-performance curtainwall glazing system with operable windows, which was designed to maximize natural daylight exposure into the interior resulting in $75 \%$ of the office floor area being provided with daylight. Every window blind in every office has two motors that are programmed to respond to changes in the weather, and in the interior environment; adjust to the sun's position to maximize natural light; bring in fresh air; and reduce reliance on conventional lighting, heating and air conditioning. The primary artificial lighting system uses photo and occupancy sensors to detect conditions and dim overhead lights when needed. Lighting energy use is reduced by about $45 \%$ with the use of this daylight dimming system. Reflective lighting, controlling indoor lights and shading with an automated blind system after dark, controls light pollution. (Olmstead and Neely, 2005; Schneider-electric, 2008; USGBC, 2012b)

The natural light enhancement system at the atrium utilizes a series of roof-mounted heliostats (prismatic louvers) that track the sun's movement across the sky to fixed mirrors and provide sufficient natural light for at least $75 \%$ of the workspaces. The fixed mirrors and the movable louvers keep bouncing the glaring, direct sunlight between themselves, allowing the diffused light to enter the atrium. On entering the atrium, the light is further reflected to the floors by a system of hanging prismatic mobiles, reflective panels, and a reflective light wall on the inner surface of the atrium. (Olmstead and Neely, 2005; Schneider-electric, 2008; USGBC, 2012b)

Ventilation can be increased if carbon dioxide sensors register inadequate indoor air conditions and fan coil units are automatically shut off when windows or doors are opened for natural ventilation. (Genzyme, 2008; Olmstead and Neely, 2005)

The building uses $32 \%$ less water than a comparable office building through the use of automated faucets in toilets and soil sensors for irrigation. The vegetated roof is irrigated when soil sensors indicate the need, which saves 753,297 litres each year, which is more than the building's projected total irrigation water usage. A buildingcommissioning plan was put in place to monitor, measure and verify the operation of key building equipment and systems prior to as well as post building occupancy. (USGBC, 2012b)

\subsection{Asia Square Tower 1, Singapore}

The technologically advanced design of Asia Square Tower 1 has created greater business efficiency, less duplication of common resources and reduced occupancy costs by up to $20 \%$. The 117,000 sq.m., office and retail centre at Marina Bay in Singapore has been awarded with a LEED 'PLATINUM' rating in 2011.

The highly integrated Intelligent Building Management System (IBMS) is like a centralized brain and keeps a constant check on all the building systems. Photo sensors connected to the IBMS, control office floor perimeter lighting providing an average illumination intensity of 500 lux. The IBMS optimizes supply of fresh air into the building by monitoring the level of carbon dioxide and carbon monoxide using a $\mathrm{CO} 2$ sensor system. Additionally it also removes stagnant air from the office space by periodic air purging. Air Handling Units are fitted with ultra-violet emitters that improve indoor air quality by removing harmful airborne microorganisms. The IBMS also regulates indoor air temperature and controls the air conditioning on a per zone basis for after office hour's operations. (Asia-Square, 2012)

The security and property management systems ensure maximum workplace efficiency. The sophisticated smart card access system uses proximity card readers to control access to lift lobbies and the foyer, by use of turnstiles linked to the regenerative power saving and fully automated destination-controlled lift system whilst 
ensuring the shortest travelling time between floors. 24hour CCTV monitors are used for surveillance of car parks; lift lobbies; and other sensitive areas. Additionally a Guard Tour System is provided to track manual security inspections at frequent intervals. The Fire Protection System incorporates fire detection and wet sprinkler systems. Fully independent communications and information transfer is made possible through the use of multiple communication risers, which keeps the business safely connected to the world. (Asia-Square, 2012)

\subsection{Taipei 101 Tower, Taiwan}

The Taipei 101, which is 508 meters tall and 194,000 sq.m. in area is an outstanding landmark signifying Taiwan's economic and technological progress. Innovative technologies and high-tech materials helped the office and retail tower achieve a LEED 'PLATINUM' rating in 2011 (USGBC, 2012c).

The Energy Management and Control System (EMCS) tests and manages all building systems with its primary objective being minimizing environmental impact. The EMCS has helped Taipei 101 to secure a rank in the top $30 \%$ of high-rise office buildings as benchmarked by the U.S. ENERGY STAR database. It has also helped reduce energy consumption by 33.41 million $\mathrm{kWh}$ per year and to save more than US\$2 million per year. Water management systems and low-flow water fixtures effectively reduced water usage and helped Taipei 101 decrease potable water usage by at least $30 \%$ as compared to average building consumption, saving about 28,000,000 litres of potable water annually. (USGBC, 2012c)

Taipei 101 has installed one of the worlds most advanced, customized, integrated electronic security systems that is designed to provide constant control and monitoring of the tower. The surveillance system has 420 CCTV cameras and other security facilities that effectively transmit real time security feeds of all main entrances, elevators and common areas through an optical cable network. A fully computerized smartcard access control system is present throughout the building at all key points of ingress and circulation and controls access to building entrances, car parks, lobbies, elevators, office floors and fire escape doors. The Visitor Access Kiosk System (VAKS) tightens security by issuing authorized visitors with temporary access cards to access the optically controlled gate and keeps their photographic records. When a tenant wants to access his office floor out of office hours, the security mode of the elevator is activated when he swipes his card at the Elevator Card Reader and arrives only at his designated floor. (Taipei101, 2009)

Addressable detectors and CCTV cameras are used in the tower for fire monitoring. The detectors continuously collect air samples to detect unusual fog and ensure fire safety. The Fire Protection system ensures that the air conditioning automatically cuts off where smoke is detected and an automatic sprinkler system is activated. Office floors and key escape routes are protected by a smoke exhaust system. (Taipei101, 2009) The tower has the most advanced integrated telecommunications infrastructure. Two fibre-optic backbones, from separate central stations, enter the building at different points. To provide further telecom redundancy, the tower is equipped with three alternative means of communication: Microwave, Free Space Optics and Satellite. (Taipei101, 2009; USGBC, 2012c)

\subsection{Summary}

It can be observed that the intelligent building technologies used in the above case studies can be categorized functionally in broader groups namely Integrated Building Automation, Lighting, HVAC, Water management, Security, Fire safety and IT. Table 3 provides a summary of all the intelligent technologies used.

Table 4 is a compilation of benefits achieved through the use of these intelligent technologies. The table highlights the reduction in energy consumption, water usage and operational costs as well as improvement in user well being and productivity. It goes on to prove that intelligent technologies have contributed to the overall sustainability of the buildings and thus helped them acquire a high sustainability rating on the LEED rating system.

\subsection{Benefits}

It can be reported through the study of literature and case studies that intelligent buildings provide various benefits on the environmental, economic and social front. They have the potential to promote high efficiency spaces and low-energy consumption, which can be the answer to a multitude of environmental concerns. They can also reduce water usage as well as the release of harmful green house gases into the atmosphere. (Ehrlich, 2007; RiosMoreno et.al., 2007; Clarke, 2008; Mazza, 2008; Moore 2009a; Wu and Noy, 2010; Liu et.al., 2010; Kolodny, 2011; Pandharipande and Caicedo, 2011) Intelligent buildings are known to enrich the social experience of occupants through the provision of improved user comfort, safety, security, social ambience, sensory stimulation, and better indoor air quality and illumination levels. It can be safely assumed that intelligent spaces provide enhanced living environments that provide for social sustenance. (Wacks, 2002; Clements-Croome, 2004; Matthew et al., 2009; Chappells, 2010; Chen et. al., 2010; Karjaleinen, 2010; Moran and Nakata, 2010) Additionally intelligent buildings significantly lower operating costs with accurate monitoring and control of energy intensive building systems to make a bankable difference (Himanen, 2003; Pitts, 2004; Gray, 2006; Madsen, 2008a; Mazza, 2008; Matthew et. al., 2009). Intelligent building technologies give building management professionals the tools they need to better serve tenants, occupants, and users. A significant benefit to the building owner is that intelligent buildings will get above-market rents, have lower vacancy rates, and additional revenue expectations (ClementsCroome, 1997; Harisson et al., 1998; Gray, 2006; Matthew et al., 2009; Katz and Skopek, 2009).

In conclusion, it can be suggested that the main operational benefits of installing intelligent building components include:

- energy efficiency and higher environmental sustainability;

- increased user comfort and productivity;

- improved safety and reliability;

- improved operational effectiveness; and

- enhanced cost effectiveness. (Gadakari et al., 2012) 
Table 3. List of intelligent technologies

\begin{tabular}{|c|c|}
\hline Case Study & Intelligent Building Technologies Used \\
\hline $\begin{array}{l}\text { 5.1. Herman Miller International } \\
\text { Headquarters, UK }\end{array}$ & $\begin{array}{l}\text { - Computerized ventilation system } \\
\text { - Motorized fanlight opening for windows } \\
\text { - Automatic night-cooling strategy } \\
\text { - Sensors in the floor slabs } \\
\text { - Water meters } \\
\text { - Sensor controlled lighting strategy } \\
\text { - Photographic identity cards } \\
\text { - CCTV surveillance } \\
\text { - Electronic document management system } \\
\text { - Sub-metering }\end{array}$ \\
\hline $\begin{array}{l}\text { 5.2. The U.S. Green Building Council } \\
\text { (USGBC) Headquarters, USA }\end{array}$ & $\begin{array}{l}\text { - Lighting system controlled off of an IT backbone } \\
\text { - Motorized window shades } \\
\text { - Occupancy sensors for lighting and plugs } \\
\text { - Automated temperature modulation } \\
\text { - Integrated lighting and HVAC system } \\
\text { - Ventilation system with two-position diffuser } \\
\text { - Sub-metering }\end{array}$ \\
\hline 5.3. Genzyme Centre, USA & $\begin{array}{l}\text { - Automated curtainwall glazing system } \\
\text { - Automated blind system } \\
\text { - Natural light enhancement system } \\
\text { - Ventilation system with CO2 sensors } \\
\text { - Automated faucets } \\
\text { - Soil sensors for irrigation } \\
\text { - Building-commissioning plan }\end{array}$ \\
\hline 5.4. Asia Square Tower 1, Singapore & $\begin{array}{l}\text { - Integrated Intelligent Building Management System } \\
\text { - CO2 sensor system } \\
\text { - Photo sensors } \\
\text { - Air Handling Units with ultra-violet emitters } \\
\text { - Zoned HVAC system } \\
\text { - Property management system } \\
\text { - Smart card access system with proximity card readers } \\
\text { - Automated destination-controlled lift system } \\
\text { - CCTV surveillance } \\
\text { - Guard Tour System } \\
\text { - Fire Protection System } \\
\text { - Multiple communications and information risers }\end{array}$ \\
\hline 5.5. Taipei 101 Tower, Taiwan & $\begin{array}{l}\text { - Energy Management and Control System } \\
\text { - Water management system } \\
\text { - Integrated electronic security systems } \\
\text { - CCTV surveillance } \\
\text { - Computerized smartcard access control system } \\
\text { - Visitor Access Kiosk System } \\
\text { - Optically controlled gates } \\
\text { - Automated destination-controlled lift system } \\
\text { - Fire Protection system } \\
\text { - Smoke exhaust system } \\
\text { - Multiple communications and information risers }\end{array}$ \\
\hline
\end{tabular}

\subsection{Common Attributes}

It can be observed that the benefits of intelligent buildings contribute to the 'triple bottom line' of sustainable development i.e. the environmental, economic and social aspects. Intelligent buildings are smarter, better connected, self-monitoring spaces providing safer, comfortable, secure, efficient environments capable of self-managing utilities; and maximising occupant performance, investment and operating cost, savings and flexibility. The aforementioned characteristics bear resemblance to the common objectives of sustainable buildings that are designed to reduce the overall impact of the built 
environment on the natural environment, human health and economy by:

- Efficiently using energy, water, and other resources

- Protecting occupant health and improving employee productivity

- Reducing waste, pollution and environmental degradation.

As is evident intelligent buildings and sustainable buildings are striving towards common goals. In keeping with this theme the Continental Automated Buildings Association (CABA) has introduced the concept of being intelligent, green, and profitable which is aptly described as a Bright Green Building. "A bright green building is one that is both intelligent and green. It is a building that uses both technology and process to create a facility that is safe, healthy and comfortable, and enables productivity and well being for its occupants" (Frost and Sullivan, 2009).

Table 4. Summary of findings from the case studies

\begin{tabular}{|c|c|c|c|c|}
\hline Case Study & Environmental & Economic & Social & $\begin{array}{c}\text { Total } \\
\text { Sustainability }\end{array}$ \\
\hline $\begin{array}{l}\text { 5.1. Herman } \\
\text { Miller } \\
\text { International } \\
\text { Headquarters, } \\
\text { UK }\end{array}$ & $\begin{array}{l}\text { Office space with } \\
\text { intelligent lighting } \\
\text { strategy uses almost } 4 \\
\text { times less energy than } \\
\text { retail space of smaller } \\
\text { floor area, with } \\
\text { conventional lighting. } \\
\text { Water wastage is } \\
\text { prevented. }\end{array}$ & $\begin{array}{l}\text { Intelligent lighting } \\
\text { strategy and a } \\
\text { computerized ventilation } \\
\text { system helped increase } \\
\text { operational savings. }\end{array}$ & $\begin{array}{l}\text { Staff safety, efficiency } \\
\text { and productivity } \\
\text { improved. }\end{array}$ & $\sqrt{ }$ \\
\hline $\begin{array}{l}\text { 5.2. The U.S. } \\
\text { Green Building } \\
\text { Council } \\
\text { (USGBC) } \\
\text { Headquarters, } \\
\text { USA }\end{array}$ & $\begin{array}{l}60 \% \text { less energy and } 40 \% \\
\text { water savings than a } \\
\text { typical code-compliant } \\
\text { office. Integration of } \\
\text { intelligent lighting } \\
\text { controls and automated } \\
\text { temperature modulation } \\
\text { resulted in a } 15 \% \text { drop in } \\
\text { energy usage. }\end{array}$ & $\begin{array}{l}\text { US } \$ 96,000 \text {-per-year } \\
\text { savings and a low } \\
\text { payback period. }\end{array}$ & $\begin{array}{l}\text { Increased staff } \\
\text { productivity. }\end{array}$ & $\sqrt{ }$ \\
\hline $\begin{array}{l}\text { 5.3. Genzyme } \\
\text { Centre, USA }\end{array}$ & $\begin{array}{l}\text { The daylight dimming } \\
\text { system reduces lighting } \\
\text { energy use by } 45 \% \text {. The } \\
\text { building uses } 32 \% \text { less } \\
\text { water than a comparable } \\
\text { office building and saves } \\
753,297 \text { litres of water a } \\
\text { year. }\end{array}$ & $\begin{array}{l}\text { The building } \\
\text { management system has } \\
\text { reduced the overall } \\
\text { energy cost by } 41 \% \text {. }\end{array}$ & $\begin{array}{l}\text { The high performance } \\
\text { curtain wall glazing } \\
\text { system and the natural } \\
\text { light enhancement } \\
\text { system maximise natural } \\
\text { daylight exposure to } 75 \% \\
\text { and bring in fresh air. }\end{array}$ & $\sqrt{ }$ \\
\hline $\begin{array}{l}\text { 5.4. Asia } \\
\text { Square Tower } \\
\text { 1, Singapore }\end{array}$ & $\begin{array}{l}\text { The Intelligent Building } \\
\text { Management System } \\
\text { (IBMS) improved energy } \\
\text { efficiency. }\end{array}$ & $\begin{array}{l}\text { Reduction in operating } \\
\text { costs by } 20 \% \text {. }\end{array}$ & $\begin{array}{l}\text { State-of-art security, fire } \\
\text { protection and property } \\
\text { management systems } \\
\text { ensured greater business } \\
\text { efficiency. }\end{array}$ & $\sqrt{ }$ \\
\hline $\begin{array}{l}\text { 5.5. Taipei } 101 \\
\text { Tower, Taiwan }\end{array}$ & $\begin{array}{l}\text { The Energy Management } \\
\text { and Control System } \\
\text { (EMCS) reduces energy } \\
\text { consumption by } 33.41 \\
\text { million kWh per year and } \\
\text { potable water usage by } \\
30 \% \text {, saving } 28 \text { million } \\
\text { litres of water a year. }\end{array}$ & $\begin{array}{l}\text { The Energy Management } \\
\text { and Control System } \\
\text { (EMCS) saves more than } \\
\text { US } \$ 2 \text { million per year. }\end{array}$ & $\begin{array}{l}\text { The integrated security } \\
\text { system comprising of } \\
\text { surveillance, smartcard } \\
\text { access control, visitor } \\
\text { access kiosk and fire } \\
\text { protection systems } \\
\text { provide the tenants with } \\
\text { advanced safety features. }\end{array}$ & $\sqrt{ }$ \\
\hline Conclusion & $\begin{array}{l}\text { Communication between } \\
\text { various building systems } \\
\text { through a centralized } \\
\text { system can lead to } \\
\text { increased energy savings } \\
\text { as opposed to a stand- } \\
\text { alone system. }\end{array}$ & $\begin{array}{l}\text { The return on investment } \\
\text { due to the energy and } \\
\text { operational cost savings } \\
\text { have reduced the } \\
\text { payback period for most } \\
\text { of the intelligent building } \\
\text { equipments. }\end{array}$ & $\begin{array}{l}\text { Smart features of an } \\
\text { intelligent system can } \\
\text { enhance the overall well- } \\
\text { being of people which } \\
\text { translates to improved } \\
\text { efficiency and } \\
\text { productivity in the } \\
\text { workplace. }\end{array}$ & $\begin{array}{l}\text { Use of intelligent } \\
\text { systems has } \\
\text { reported benefits } \\
\text { on the } \\
\text { environmental, } \\
\text { economic and } \\
\text { social fronts. }\end{array}$ \\
\hline
\end{tabular}




\subsection{Limitations}

In spite of these purported benefits, the main barriers to the promotion and acceptance of intelligent buildings can be attributed to the lack of:

- financial resources and confidence to undertake new and 'untested' technologies;

- professional capacity to incorporate and manage intelligent technologies;

- knowledge of developers and owners on the environmental impact of inefficient buildings;

- information on opportunities presented by intelligent technologies;

- institutional structures to encourage and support uptake of such technologies. (Gadakari et.al., 2012)

\section{Conclusion}

With the advent of various intelligent building technologies, in the times when sustainable development is a rising concern, it was quite necessary to assess whether intelligent development is sustainable or not. By conducting this review of existing literature, theoretical concepts and case studies the researcher aspires to provide an optimized solution of sustainability and intelligence that will help the agenda of living in a healthy, comfortable, and technologically advanced world. The study started with a review of existing intelligent building literature compared against the theoretical framework of sustainability. It was followed by an analysis of five case studies from around the world to showcase the role of intelligent building systems in achieving total sustainability.

This article has reviewed key concepts pertaining to intelligent buildings and sustainable development to provide documented evidence that sustainability could be achieved using intelligent technology. A thorough awareness of the academic context helped in the identification of common attributes to both intelligent and sustainable buildings. It can be suggested through this research that intelligent buildings are sustainable on all the three fronts analyzed i.e. environmental, economic and social though a few inconsistencies were noted in each field. The case study research also highlighted that the use of intelligent building technologies has contributed towards a higher sustainability rating on the LEED rating scale. Implications from the study also theorize that though intelligent buildings have a positive impact on the environment, people and economy there is still a wide scope for enhancement.

Owing to the continuous, evolving technological progress that intelligent buildings are a part of, this subject area warrants further exploration. This study has set down the foundation for a meticulous examination of intelligent buildings and sustainability in the built environment context. From a practical perspective, it provides a way for developers or design teams to value sustainability of intelligent systems and lay emphasis on a sustainable design strategy. It can help set up industry standards in the future, which clients can refer to and decide the best suited intelligent green design for their organizational needs.

\section{References}

Alnakib, E. (2004). Sustainability as a design paradigm for quality architecture. $\mathrm{PhD}$ Thesis, University of New South Wales.

Asia-Square (2012). Welcome to the Human Building. Retrieved from http://www.thehumanbuilding.com/ on September 29, 2012.

Atkin, B. (1988). Progress towards Intelligent Building. in Atkin, B. (ed.) Intelligent Buildings- Applications of IT and Building Automation to High Technology Construction Projects. London: Unicom Seminars limited.

Baird, G. and Lechat, S. (2009). Users' Perceptions of Personal Control of Environmental Conditions in Sustainable Buildings. Architectural Science Review, 52(2), 108-116. doi: 10.3763/asre.2009.0013

Barnes, N.M., Edwards, N.H., Rose, D.A.D., and Garner, P. (1998). Lifestyle monitoring-technology for supported independence. Computing \& Control Engineering Journal, 9(4), 169-174.

Behnisch-Architekten (2012). Projects: Genzyme Center. Retrieved from http://behnisch.com/projects/104 on August 14, 2012.

BRE (2011). Intelligent Building: BRE's intelligent buildings group. Retrieved from http://www. bre.co.uk/page.jsp?id=725 on September 9, 2011.

Chappells, H. (2010). Comfort, well-being and the sociotechnical dynamics of everyday life. Intelligent Buildings International, 2(4), 286-298. doi: 10.3763/inbi.2010.0003

Chen, J., Ma, Y., Jeng, T., and Chang, C. (2010). An assessment of user needs for intelligent living space. Intelligent Buildings International, 2(1), 20-40. doi: 10.3763/inbi.2009.0031

Clarke, E. (2008). The truth about... intelligent buildings. Retrieved from http://www.climatechangecorp.com/ content.asp?ContentID=5471 on February 1, 2012.

Clements-Croome, D. (1997). What do we mean by intelligent buildings? Automation in Construction.

Clements-Croome, D. (ed.) (2004). Intelligent Buildings: Design, Management and Operation. London: Thomas Telford.

Cole, R. and Brown, Z. (2009). Reconciling human and automated intelligence in the provision of occupant comfort. Intelligent Buildings International, 1(1), 3955. doi: 10.3763/inbi.2009.0007

Damodaran, R. (2006). Intelligent buildings. Retrieved from http://propertybytes.indiaproperty.com/index. php/architecture-interiors/intelligent-buildings on February 1, 2012.

Designbuild-Network (2012). VillageGreen, Herman Miller International Headquarters, United Kingdom. Retrieved from http://www.designbuild-network. com/projects/villagegreen/ on September 24, 2012.

Dounis, A.I., Tiropanis, P., Argiriou, A., and Diamantis, A. (2011). Intelligent control system for reconciliation of the energy savings with comfort in buildings using soft computing techniques. Energy and Buildings, 43(1), 66-74. doi: 10.1016/j.enbuild.2010.08.014

Ehrlich, P. (2007). Intelligent Buildings Today. Retrieved from http://www.greenintelligentbuildings.com/ Articles/Cover_Story/BNP_GUID_9-52006_A_10000000000000056794 on May 9, 2010.

Elkadi, H. (2000). Ecological approach for the evaluation of intelligence energy features in a building's skin. Renewable and Sustainable Energy Reviews, 4(1), 91103. 
Elkington, J. (2004). Enter the Triple Bottom Line. in Henriques, A. and Richardson, J. (eds.) The Triple Bottom Line, Does it All Add Up?: Assessing the Sustainability of Business and CSR. London: Earthscan, 1-16.

Farinloye, O., Odusami, K., and Adewunmi, Y. (2013). Theft and Vandalism Control Measures on Building Sites in Lagos, Nigeria. Journal of Engineering, Project, and Production Management, 3(1), 9-21.

Frost and Sullivan (2009). The Bright Green Buildings Convergence of Green and Intelligent Buildings. Continental Automated Buildings Association (CABA). Retrieved from http://www.caba.org/brightgreen on June 16, 2011.

Futureagenda (2011). Intelligent Buildings. Retrieved from http://www.futureagenda.org/pg/cx/view\#415 on December 7, 2011.

Gadakari, T., Mushatat, S., and Newman, R. (2012) Can Intelligent Buildings Lead Us to a Sustainable Future? 3rd International Conference on Engineering, Project and Production Management. Brighton, UK 10-11 September 2012, pp.335-346.

Garner, R. (1996). Environmental Politics. Hertfordshire: Harvester Wheatsheaf.

Genzyme (2008). Welcome to Genzyme Center, Cambridge, MA. Retrieved from http://www. genzymecenter.com/ on August 14, 2012.

Gray, A. (2006). How Smart are Intelligent Buildings? Retrieved from http://www.facilitiesnet.com/ buildingautomation/article/How-Smart-AreIntelligent-Buildings--5222 on January 9, 2012.

Gonchar, J. (2009). Case Study: USGBC Headquarters. GreenSource: The Magazine of Sustainable Design. Retrieved from http://greensource.construction.com/ green_building_projects/2009/0911_USGBCheadquarters.asp on July 8, 2012.

Gore, A. (2006). An Inconvenient Truth: The Planetary Emergency of Global Warming and What We Can Do About It. London: Bloomsbury Publishing Plc.

Harris, F. (2004). Sustainable Development. in Harris, F. (ed.) Global Environmental Issues. West Sussex: John Wiley and Sons Ltd.

Harrison, A., Loe, E., Read, J. (1998). Intelligent Buildings in South East Asia. London: Taylor \& Francis Routledge.

Hartman, T. (2005). What's The Role For Advanced Technologies In Green Building Design? Engineered Systems. Retrieved from http://www. automatedbuildings.com/news/aug05/articles/ibtth/ibtt h.htm on March 16, 2013.

HermanMiller (2008). Village life: A guide for VillageGreen residents. Retrieved from http://www.bdonline.co.uk/Journals/Builder_Group/B uilding_Design/10_October_2008/attachments/vghan dbook.pdf on September 24, 2012.

HermanMiller (2013) International Headquarters: VillageGreen. Retrieved from http://www. hermanmiller.co.uk/VillageGreen.aspx on February $15,2013$.

Himanen, M. (2003). The Intelligence of Intelligent Buildings: The Feasibility of the Intelligent Building Concept in Office Buildings. Doctor of Science in Technology Thesis, Helsinki University of Technology.

IT-Online (2012). Intelligent buildings save energy. Retrieved from http://www.it-online.co.za/ 2012/01/09/intelligent-buildings-save-energy/

on January 14, 2012.

Karjalainen, S (2010). Usability guidelines for room temperature controls. Intelligent Buildings International, 2(1), 85-97. doi: 10.3763/ inbi.2010.0020

Katz, D. and Skopek, J. (2009). The CABA Building Intelligence Quotient programme. Intelligent Buildings International, 1(4), 277-295. doi: 10.3763/inbi.2009.SI05

Kluver, R. (2000). Globalization, Informatization, and Intercultural Communication. American Journal of Communication. Retrieved from http://unpan1.un.org/ intradoc/groups/public/documents/apcity/unpan00200 6.htm on February 3, 2012.

Kolodny, L. (2011). IBM "Buildings Whisperer" Dave Bartlett On The Dumb Ways We Waste Energy. Retrived from http://techcrunch.com/2011/06/27/ibmintelligent-buildings-mgmt-solution-tctv/ December 12, 2011.

Kua, H. and Lee, S. (2002). Demonstration intelligent building - a methodology for the promotion of total sustainability in the built environment. Building and Environment, 37(3), 231-240.

Kurzweil, R. (2005). The Singularity is Near: When Humans Transcend Biology. New York: Penguin Group.

Lai, E. (2006). Microsoft: Future homes to use smart appliances, interactive wallpaper. Retrieved from http://www.computerworld.com/s/article/9003752/Mi crosoft_Future_homes_to_use_smart_appliances_inter active_wallpaper on April 16, 2012.

Liu, K., Nakata, K., and Harty, C. (2010). Pervasive informatics: theory, practice and future directions. Intelligent Buildings International, 2(1), 5-19. doi: 10.3763/inbi.2009.0041

Madsen, J.J. (2008). The Realization of Intelligent Buildings. Buildings (102 ed.). 38-44. Retrieved from http://www.buildings.com/ArticleDetails/tabid/3334/ Default.aspx?ArticleID=5736\#top on December 12, 2011.

Matsunawa, K. and Nohara, F. (1994). Intelligent building saves energy. ASHRAE Journal, January, 3840.

Matthew, P., Mukherjee, M., and Gupta, V. (2009). The Performance of Intelligent Buildings in India. The Institution of Engineers (India) Journal, 90(April).

Mazza, P. (2008). Making green buildings intelligent: how to link green buildings and the Smart Grid. Retrieved from http://www.smartgridnews.com/ artman/publish/Industry/Making_green_buildings_int elligent_how_to_link_green_buildings_and_the_Smar t_Grid_printer.html on December 12, 2011.

Mitchell, W.J. (1998). Dematerialization, Demobilization and Adaptation. in Scott, A. (ed.) Dimensions of Sustainability: architecture, form, technology, environment, culture. London: E \& FN Spon.

Moore, C.A. (2009a). The Role Of Lighting And HVAC Systems In Green Campuses. Retrieved from http://www.facilitiesnet.com/educationalfacilities/artic le/The-Role-of-Lighting-and-HVAC-Sytems-inGreen-Campuses--10658\# on December 1, 2011.

Moore, C.A. (2009b). Intelligent Buildings Are Green. Retrieved from http://www.facilitiesnet.com/ educationalfacilities/article/Intelligent-Buildings-AreGreen--10657 on December 3, 2011. 
Moran, S. and Nakata, K. (2010). Analysing the factors affecting users in intelligent pervasive spaces. Intelligent Buildings International, 2(1), 57-71. doi: 10.3763/inbi.2009.0040

Newsham, G., Mancini, S., Veitch, J., Marchand, R., Lei, W., Charles, K., and Arsenault, C. (2009). Control strategies for lighting and ventilation in offices: effects on energy and occupants. Intelligent Buildings International, 1(2), 101-121. doi: 10.3763/inbi.2009.0004

Nikolaou, T., Kolokotsa, D., and Stavrakakis, G. (2004). Introduction to Intelligent Buildings. in A Handbook for Intelligent Buildings. Athens: SMART Accelerate.

Olmstead, D. and Neely, D. (2005). Genzyme CenterHeadquarters for Genzyme Corporation: Shedding New Light on Sustainable Building Strategies. Massachusetts: Tufts Climate Initiative \& Tufts University Department of Urban and Environmental Policy and Planning.

O'Neill, S. (2010) Microsoft's Home of the Future: A Visual Tour. Retrieved from http://www.cio.com/ article/597693/Microsoft_s_Home_of_the_Future_A_ Visual_Tour?page=1\#slideshow on April 25, 2013.

Pandharipande, A. and Caicedo, D. (2011). Daylight integrated illumination control of LED systems based on enhanced presence sensing. Energy and Buildings, 43(4), 944-950. doi: 10.1016/j.enbuild.2010.12.018

Parker, J. (2009). Model project - Herman Miller UK HQ. Retrieved from http://www.bsria.co.uk/news/ article/herman-miller// on September 24, 2012.

Pitts, A. (2004). Planning and Design Strategies for Sustainability and Profit: Pragmatic sustainable design on building and urban scales. Oxford: Architectural Press.

Riewoldt, O. (1997). Intelligent Spaces: Architecture for the Information Age. London: Laurence King Publishing.

Rios-Moreno, G., Trejo-Perea, M., Castaneda-Miranda, R., Hernandez-Guzman, V., and Herrera-Ruiz, G. (2007). Modelling temperature in intelligent buildings by means of autoregressive models. Automation in Construction, 16(5), 713-722. doi: 10.1016/j.autcon.2006.11.003

Schultz, B. (2010). Building Smart for Sustainability. ON Magazine. Retrieved from http://www.emc.com/ leadership/features/building-smart-forsustainability.htm on March 16, 2013.

Scott, A. (ed.) (1998). Dimensions of Sustainability: architecture, form, technology, environment, culture. London: E \& FN Spon.

Schneider-electric (2008). Project Profile: Genzyme Center. Retrieved from http://www.schneiderelectric.co.uk/documents/buildings/genzyme.pdf on August 14, 2012.

Sen, A.K. (2000). The ends and means of sustainability. International Conference on Transition to sustainability. Tokyo.

Sharples, S., Callaghan, V., Clarke, G. (1999). A MultiAgent Architecture For Intelligent building sensing and control. Sensor Review, 19(2), 135-140.

Taipei101 (2009). Taipei 101 Tower. Retrieved from http://www.taipei-101.com.tw/index_en.html on August 9, 2012.
USGBC (2009). U.S. Green Building Council Headquarters Washington, DC. Retrieved from http://www.usgbc.org/Docs/Archive/General/Docs697 3.pdf on July 8, 2012.

USGBC (2012a). USGBC Headquarters. Retrieved from http://www.usgbc.org/projects/usgbc-headquarters? view=overview on July 8, 2012.

USGBC (2012b). Genzyme Center. Retrieved from http://leedcasestudies.usgbc.org/overview.cfm?Project ID $=274$ on August 14, 2012.

USGBC (2012c). TAIPEI 101 Tower. Retrieved from http://www.usgbc.org/projects/taipei-101-tower-0? view=overview on August 9, 2012.

WCED, 1987. Report of the World Commission on Environment and Development: Our Common Future. United Nations General Assembly.

Wacks, K.P. (2002). Best-Practices Guide for Evaluating Intelligent Building Technologies. Ottawa: CABA North America's Home \& Building Automation Association.

Workplace intelligence (2012). VillageGreen relocation. Retrieved from http://s200941466.websitehome. co.uk/uploads/files/VillageGreen_relocation.pdf on September 24, 2012.

$\mathrm{Wu}, \mathrm{S}$. and Noy, P. (2010). A conceptual design of a wireless sensor actuator system for optimizing energy and well-being in buildings. Intelligent Buildings International, 2(1), 41-56. doi: 10.3763/inbi. 2009.0032

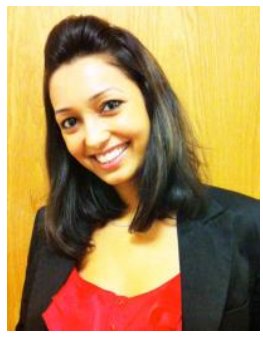

Tulika Gadakari is currently pursuing a PhD at the Faculty of Science and Engineering, University of Wolverhampton that explores the relationship between Intelligent Buildings and Environmental Sustainability. She obtained a Master's degree in Sustainable Architectural Studies from the University of Sheffield in 2010 and graduated as an Architect from the Sir J.J. College of Architecture, Mumbai, India in 2008. She is the co-founder and director of 'The Green Labs', which is a multidisciplinary consultancy firm providing, integrated design solutions for technologically advanced sustainable buildings. As an architect she has a varied experience of working on industrial and residential developments, urban townships and interior design.

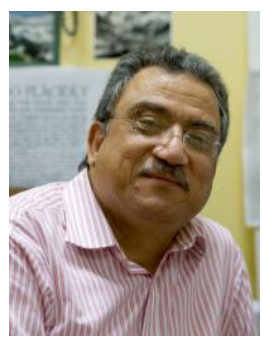

Professor Sabah Mushatat is a Professor of Architecture at the Faculty of Science and Engineering, University of Wolverhampton, concentrating mainly on the fields of environmental and sustainable design. He has taught architecture for 28 years in the Middle East and Europe and is a chartered member of the Royal Institute of British Architects (RIBA). He has served as an expert on several scientific bodies, such as UNEP, UNESCO, and ALESCO. He has published about 80 research papers in refereed journals and conferences as well as several books and textbooks. 


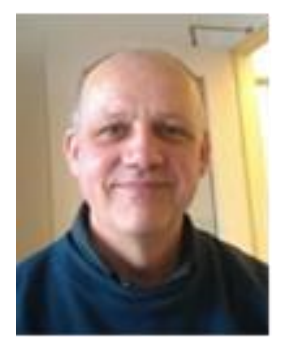

Professor Robert Newman is the Associate Dean at the Faculty of Science and Engineering, University of Wolverhampton, with the responsibility for research and academic development. He received his BSc in Physics from the University of Birmingham in 1976, and his $\mathrm{PhD}$ in Computer Science from Coventry University in 1998. In the course of his long and varied research career, Robert has successfully secured and delivered research contracts worth in excess of $£ 1 \mathrm{M}$, funded by the European Union and by EPSRC. His research focus lies in pervasive computing, specializing in the system design of distributed intelligent systems and their application within very large wireless intelligent sensor networks. 